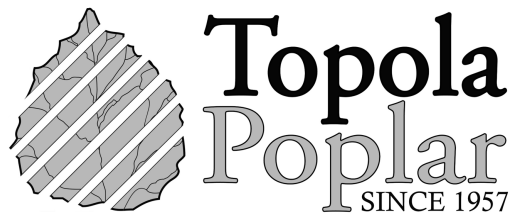

\title{
Effect of IBA and TIBA on rhizogenesis of Wild cherry in vitro
}

\author{
Vanja Vuksanović ${ }^{*}$, Branislav Kovačević ${ }^{2}$, Lazar Kesić2 ${ }^{2}$ Lazar Pavlović', Erna Vaštag1, Marko \\ Kebert $^{2}$ \\ 1 University of Novi Sad, Faculty of Agriculture, Novi Sad, Serbia \\ 2 University of Novi Sad, Institute of Lowland Forestry and Environment, Novi Sad, Serbia \\ * Corresponding author: Vanja Vuksanović; E-mail: vanja.vuksanovic@polj.uns.ac.rs
}

Received: 30 Sep 2020; Revised: 2 Oct 2020; Accepted: 15 Oct 2020

\begin{abstract}
Nowadays, considerable attention is paid to wild cherry (Prunus avium L.) due to its economic and ecological importance. This fast-growing noble tree species is highly valued in furniture industry, while preservation and restoration of its genetic variability is closely related to preservation of biodiversity in general. Along with its importance there is high interest in vegetative propagation of interesting wild cherry genotypes, especially by means of tissue culture. This technique provides relatively fast propagation and production of healthy planting material. Obtained plants are used for the establishment and improvement of seed orchards or the establishment of clonal plantations dedicated for wood production. Important phase in micropropagation of wild cherry is rooting.

In this work, results of application of indole-3-butyric acid (IBA) and 2,3,5-triiodobenzoic acid (TIBA) in rooting medium are presented, as well as the effect of medium $\mathrm{pH}$. After thirty-five days of in vitro cultivation, results of analysis of variance suggested significant effect of examined treatments on variation of parameters of rooting and survival of wild cherry explants. The best rooting and shoot growth were obtained on treatments based on modified of MS medium with $20 \mu \mathrm{IBA}$ and pH 5.8.
\end{abstract}

Keywords: Prunus avium, root, growth and development.

\section{Introduction}

Wild cherry (Prunus avium L.) is autochthonous, fast-growing noble tree species with broad areal that spans from Europe to northern Africa and western Asia. Its trees reach height of 15 to 30 meters. Beside its importance in fruit production, there is considerable interest in furniture industry in its wood, that is highly valued for its color and texture that resembles mahogany (Katičić-Bogdan et al. 2015). Beside economic this species has ecological significance because the preservation of genetic variability of this species is considered to be important part of preservation of biodiversity in general. To improve growth and the quality of timber of wild cherry, as well as tolerance to prevalent biotic and abiotic agents, long-term breeding projects have been established in a number of countries (Kobliha, 2002; Diaz and Merlo, 2008; Stanković-Neđić et al. 2018; Poljaković-Pajnik et al. 2019). Important step in wild cherry breeding is vegetative propagation of interesting genotypes (Tančeva-Crmarić and Kajba, 2016).

Conventional methods of vegetative propagation are usually time consuming and influenced by numerous hardly controllable agents. That is why micropropagation has broad application in forestry 
and horticulture, providing means for relatively low-cost and efficient mass production of healthy planting material with clonal purity, in relatively short time (Vuksanović et al. 2017; Vuksanović et al. 2019a). Numerous studies were conducted on improvement of vegetative propagation of wild cherry in vitro (Tančeva-Crmarić and Kajba, 2016).

Auxins are well known plant growth regulators related to the formation of root system. The most used auxins for rooting in vitro as well as in vivo conditions are IAA and IBA (Mansseri-Lamrioui et al. 2011). Positive effect of IBA on rooting in vitro was found in numerous studies in different species of Prunus sp. (Buyukdemirci, 2008; Šiško, 2011; Canli and Demir, 2014; Sarropoulou et al. 2014; Xu et al. 2015; Kumar et al. 2020; Zamanipour et al. 2015). While 2,3,5-triiodobenzoic acid (TIBA) is well known as the inhibitor of polar transport of indol-acetic acid, it could, however, provoke rooting regarding site of application and concentration (McNamara and Mitchell, 1991; Kovačević et al. 2013a).

The aim of this work was to optimize procedure for rooting in vitro of autochtonous wild cherry 8 A genotype interesting for preservation and improvement of biodiversity.

\section{Material and methods}

The wild cherry (Prunus avium L.) genotype 8A is used in this study. This genotype was chosen by positive selection from the natural stand in vicinity of village Molovin $\left(45^{\circ} 10^{\prime} \mathrm{N} ; 19^{\circ} 18^{\prime} \mathrm{E}\right)$ in Northwestern part of Serbia and transferred to the gene pool of the Institute of lowland forestry and environment, University of Novi Sad, Serbia. It is characterized by good growth in tissue culture and relatively good rooting potential. Micropropagation was based on axillary buds to avoid somaclonal variability and preserve clonal uniformity. Shoot tips, $10 \mathrm{~mm}$ high, where used for the establishment of the experiment. Concentrations of IBA and TIBA, as well as $\mathrm{pH}$ of media of examined treatments are presented in table 1 . The $\mathrm{pH}$ on media with $\mathrm{pH} 4.0$ was regulated with citric acid and sterilized in microwave oven (Kovačević et al. 2013b; Vuksanović et al. 2019b).

Table 1. Concentrations of TIBA and IBA, with used mineral media and medium $\mathrm{pH}$.

\begin{tabular}{lcccccccccc}
\hline Medium & ACM1*) & ACM2 & ACM3 & ACM4 & ACM5 & ACM6 & ACM7 & K1 & K2 & K3 \\
\hline $\mathrm{c}($ TIBA $)(\mu \mathrm{M} / 1)$ & - & 0.1 & 0.5 & - & 0.1 & 0.5 & 0.1 & - & - & - \\
$\mathrm{c}(\mathrm{IBA})(\mu \mathrm{M} / \mathrm{l})$ & - & - & - & - & - & - & 5 & 10 & 20 & 25 \\
$\mathrm{pH}$ & 4.0 & 4.0 & 4.0 & 5.5 & 5.5 & 5.5 & 5.5 & 5.8 & 5.8 & 5.8 \\
\hline
\end{tabular}

*) Media with ACM in their label are based on ACM mineral medium (Ahuja, 1984) and those with K in their label are based on modified MS mineral medium

The treatments with ACM labels are based on ACM medium (Aspen culture medium, according to Ahuja, 1984). Treatments with $\mathrm{K}$ labels are based on $\mathrm{K}$ mineral medium obtained by modification of MS (Murashige and Skoog, 1962) with pH 5.8.

Table 2. Composition of mineral ACM (Aspen Culture Medium) (Ahuja, 1984).

\begin{tabular}{cccccc}
\hline Macroelements & $\mathrm{mg} / \mathrm{L}$ & Microelements & $\mathrm{mg} / \mathrm{L}$ & $\begin{array}{c}\text { Vitamins and } \\
\text { other ingredients }\end{array}$ & $\mathrm{mg} / \mathrm{L}$ \\
\hline $\mathrm{NH}_{4} \mathrm{NO}_{3}$ & 400 & $\mathrm{NaFe} \cdot \mathrm{EDTA}$ & 40 & Thiamin & 0.1 \\
$\mathrm{Ca}\left(\mathrm{NO}_{3}\right)_{2} \cdot 4 \mathrm{H}_{2} \mathrm{O}$ & 556 & $\mathrm{MnSO}_{4} \cdot \mathrm{H}_{2} \mathrm{O}$ & 22.3 & Nicotine acid & 0.5 \\
$\mathrm{~K}_{2} \mathrm{SO}_{4}$ & 990 & $\mathrm{ZnSO} \cdot 7 \mathrm{H}_{2} \mathrm{O}$ & 8.6 & Pyridoxin & 0.5 \\
$\mathrm{CaCl}_{2} \cdot 2 \mathrm{H}_{2} \mathrm{O}$ & 96 & $\mathrm{H}_{3} \mathrm{BO}_{3}$ & 6.2 & Sucrose & 20000 \\
$\mathrm{MgSO}_{4} \cdot 7 \mathrm{H}_{2} \mathrm{O}$ & 360 & $\mathrm{KI}$ & 0.83 & Agar & 9000 \\
$\mathrm{KH}_{2} \mathrm{PO}_{4}$ & 170 & $\mathrm{Na}_{2} \mathrm{MoO}_{4} \cdot 2 \mathrm{H}_{2} \mathrm{O}$ & 0.25 & & \\
& & $\mathrm{CuSO}_{4} \cdot 5 \mathrm{H}_{2} \mathrm{O}$ & 0.025 & & \\
& & $\mathrm{CoCl}_{2} \cdot 6 \mathrm{H}_{2} \mathrm{O}$ & 0.025 & & \\
& & &
\end{tabular}


Table 3. Composition of modified MS medium.

\begin{tabular}{cccccc}
\hline Macroelements & $\mathrm{mg} / \mathrm{L}$ & Microelements & $\mathrm{mg} / \mathrm{L}$ & $\begin{array}{c}\text { Vitamins and } \\
\text { other ingredients }\end{array}$ & $\mathrm{mg} / \mathrm{L}$ \\
\hline $\mathrm{NH}_{4} \mathrm{NO}_{3}$ & $825^{*}$ & $\mathrm{NaFe} \cdot \mathrm{EDTA}$ & 37.3 & Thiamin & 0.1 \\
$\mathrm{Ca}\left(\mathrm{NO}_{3}\right)_{2} \cdot 4 \mathrm{H}_{2} \mathrm{O}$ & - & $\mathrm{MnSO} \cdot \mathrm{H}_{2} \mathrm{O}$ & 22.3 & Nicotine acid & 0.5 \\
$\mathrm{~K}_{2} \mathrm{SO}_{4}$ & - & $\mathrm{ZnSO}_{4} \cdot 7 \mathrm{H}_{2} \mathrm{O}$ & 8.6 & Pyridoxin & 0.5 \\
$\mathrm{CaCl}_{2} \cdot 2 \mathrm{H}_{2} \mathrm{O}$ & $220^{*}$ & $\mathrm{H}_{3} \mathrm{BO}_{3}$ & 6.2 & Glycine & 2 \\
$\mathrm{MgSO}_{4} \cdot 7 \mathrm{H}_{2} \mathrm{O}$ & 370 & $\mathrm{KI}$ & 0.83 & Myo-inositol & 100 \\
$\mathrm{KH}_{2} \mathrm{PO}_{4}$ & $85^{*}$ & $\mathrm{FeSO}_{4} \cdot 7 \mathrm{H}_{2} \mathrm{O}$ & $-*$ & Sucrose & 20000 \\
$\mathrm{KNO}_{3}$ & $-*$ & $\mathrm{Na}_{2} \mathrm{MoO}_{4} \cdot 2 \mathrm{H}_{2} \mathrm{O}$ & 0.25 & Agar & 6000 \\
& \multicolumn{7}{c}{$\mathrm{CuSO}_{4} \cdot 5 \mathrm{H}_{2} \mathrm{O}$} & 0.025 & & \\
& $\mathrm{CoCl}_{2} \cdot 6 \mathrm{H}_{2} \mathrm{O}$ & 0.025 & & \\
\hline
\end{tabular}

${ }^{*}$ Modification of original MS medium (Murashige and Skoog, 1962)

Cultures were cultivated at $\mathrm{t}=26 \pm 2^{\circ} \mathrm{C}$ under white light of LED lamps that provided $3500 \mathrm{~lx} / \mathrm{m}^{2}$ under the $16 \mathrm{~h} / 8 \mathrm{~h}$ day/night photoperiod for 35 days.

\subsection{Statistical analysis}

The experiment is designed as completely randomized in three repetitions. Five shoot tips were set per jar, with three jars per medium treatment. Following traits were examined: number of first order roots, shoot height $(\mathrm{mm})$, length of the longest root $(\mathrm{mm})$, survival rate $(\%)$, and rooting percentage $(\%)$, which describes the percentage of rooting of survived explants. In order to meet normal distribution of frequencies, which is required for used tests of parametric statistics, number of roots was transformed by square root transformation $(\sqrt{X+1})$ and survival rate and rooting percentage by arcsine transformation $(\arcsin \sqrt{X})$. Results were analyzed by one-way analysis of variance and difference between treatment means tested by Fisher's Least significant difference test (LSD) at the level of $\alpha=0.05$. Relations between examined traits are presented by Pearson's correlation coefficient. Statistical analysis was performed by program package STATISTICA 13 was used (TIBCO, 2017).

\section{Results and discussion}

According to F-test, factor Medium achieved statistically significant effect on variation of all examined traits measured after 35 days of cultivation in vitro, except for length of the longest root (Table 4).

Table 4. Results of F-test of one-way factorial analysis of variance for measured traits after 35 days of in vitro culture in P. avium $\mathrm{cl}$. $8 \mathrm{~A}$.

\begin{tabular}{cc}
\hline Measured traits & F-test a) \\
\hline Number of first-order roots & $30.277^{* *}$ \\
Shoot height & $5.307^{* *}$ \\
Length of the longest root & $1.5725^{* *}$ \\
Survival rate & $4.000^{* *}$ \\
Rooting percentage & $14.067^{* *}$ \\
\hline a) - Labels for the significance of F-test: significant at the level of $\alpha=0.05^{* *}$ - significant at the level of $\alpha=0.01$
\end{tabular}

According to the Fisher's Least significant difference test (LSD-test), the highest number of firstorder roots was achieved on media $\mathrm{K} 2$ and $\mathrm{K} 3$, both based on modified MS medium with $\mathrm{pH} 5.8$, where IBA was added in concentrations $20 \mu \mathrm{M}(\approx 4 \mathrm{mg} / \mathrm{l})$ and $25 \mu \mathrm{M}(\approx 5 \mathrm{mg} / \mathrm{l})$, respectively (Table 5). Except 
for survival rate, values for all other traits were significantly lower on medium with $10 \mu \mathrm{M}$ IBA $(\approx 2$ $\mathrm{mg} / \mathrm{l})(\mathrm{K} 1)$ than on $\mathrm{K} 2$ and $\mathrm{K} 3$. The best results on treatments based on ACM mineral medium was obtained on ACM4, the medium without plant growth regulators and with medium $\mathrm{pH}$ 5.5. Survival and rooting percentage as well as length of the longest root on this medium were similar to those of $\mathrm{K} 2$, but number of roots and shoot height were with significantly lower on ACM4. The smallest number of roots (0.37) was recorded on ACM7 medium, with $5 \mu \mathrm{M}$ IBA, $0.1 \mu \mathrm{M}$ TIBA in ACM medium with $\mathrm{pH}$ 5.5. The highest shoot height $(28.93 \mathrm{~mm})$ was obtained on $\mathrm{K} 2$ medium (modified MS with $20 \mu \mathrm{M}$ IBA), while the smallest shoot height value $(17.0 \mathrm{~mm}$ ) was recorded for $\mathrm{K} 3$ medium (modified MS with $25 \mu \mathrm{M}$ IBA).

Table 5. Results of Fisher's least significant difference test for measured traits in P. avium cl. 8A.

\begin{tabular}{lccccc}
\hline $\begin{array}{c}\text { Treat- } \\
\text { ment }\end{array}$ & $\begin{array}{c}\text { Number of } \\
\text { first-order roots }\end{array}$ & $\begin{array}{c}\text { Shoot height } \\
(\mathrm{mm})\end{array}$ & $\begin{array}{c}\text { Length of the } \\
\text { longest root } \\
(\mathrm{mm})\end{array}$ & $\begin{array}{c}\text { Survival } \\
\text { rate }(\%)\end{array}$ & $\begin{array}{c}\text { Rooting } \\
\text { percentage }\end{array}$ \\
\hline ACM1 & $0.56 \mathrm{~d}$ (*) & $18.16 \mathrm{bc}$ & $41.00 \mathrm{ab}$ & $100.0 \mathrm{a}$ & $44.8 \mathrm{bc}$ \\
ACM2 & $0.44 \mathrm{~d}$ & $18.38 \mathrm{bc}$ & $40.17 \mathrm{abc}$ & $100.0 \mathrm{a}$ & $29.2 \mathrm{~cd}$ \\
ACM3 & $0.59 \mathrm{~d}$ & $20.40 \mathrm{bc}$ & $49.11 \mathrm{a}$ & $100.0 \mathrm{a}$ & $52.0 \mathrm{bc}$ \\
\hline ACM4 & $1.03 \mathrm{c}$ & $19.30 \mathrm{bc}$ & $36.13 \mathrm{abc}$ & $100.0 \mathrm{a}$ & $100.0 \mathrm{a}$ \\
ACM5 & $0.65 \mathrm{~d}$ & $21.93 \mathrm{~b}$ & $44.19 \mathrm{a}$ & $100.0 \mathrm{a}$ & $73.8 \mathrm{~b}$ \\
ACM6 & $0.65 \mathrm{~d}$ & $19.38 \mathrm{bc}$ & $41.44 \mathrm{ab}$ & $100.0 \mathrm{a}$ & $48.0 \mathrm{bc}$ \\
ACM7 & $0.37 \mathrm{~d}$ & $20.17 \mathrm{bc}$ & $37.50 \mathrm{abc}$ & $100.0 \mathrm{a}$ & $6.7 \mathrm{~d}$ \\
\hline K1 & $1.27 \mathrm{~b}$ & $20.33 \mathrm{bc}$ & $14.04 \mathrm{bc}$ & $100.0 \mathrm{a}$ & $60.6 \mathrm{bc}$ \\
K2 & $1.67 \mathrm{a}$ & $28.93 \mathrm{a}$ & $33.93 \mathrm{abc}$ & $100.0 \mathrm{a}$ & $100.0 \mathrm{a}$ \\
K3 & $1.58 \mathrm{a}$ & $17.00 \mathrm{c}$ & $11.73 \mathrm{c}$ & $90.7 \mathrm{~b}$ & $100.0 \mathrm{a}$ \\
\hline
\end{tabular}

*) Difference between values of the same traits that are labeled with the same letter are not statistically significant at the level $\alpha=0.05$

The smallest length of the longest root $(11.73 \mathrm{~mm})$ was achieved on $\mathrm{K} 3$ medium (modified MS with $25 \mu \mathrm{M}$ IBA), and the longest $(49.11 \mathrm{~mm})$ on ACM3 medium $(0.5 \mu \mathrm{M}$ TIBA, ACM medium with pH4.0). Generally, treatments with ACM mineral medium, without plant growth regulators or with TIBA tend to have longer roots then treatments with IBA. On all examined media the $100 \%$ survival rate was recorded except on $\mathrm{K} 3$ where survival rate was $90.7 \%$. The highest rooting percentage was achieved on K2 and K3, as well as on ACM4. Generally, media with TIBA or with pH4.0 achieved moderate or low rooting percentages. The lowest rooting percentage was recorded on ACM7 (6.7\%).

The simulative effect of indol 3 butiric acid in modified MS medium on rooting of wild cherry shoot tips in vitro was also reported by Ďurkovič (2006) as well as by Tančeva-Crmarić and Kajba, (2016). According to Ďurkovič (2006), $73 \%$ of rooting was achieved on medium with $0.3 \mathrm{mg} / \mathrm{l} \mathrm{IBA}$. Much higher percentage of rooting achieved Fotopoulos and Sotiropoulos (2004) in P. persica $\times$ P. amygdalus. Our study is also in concordance with results of Ružić and Vujović (2008), who achieved $72.22 \%$ of rooting percentage on medium with $5 \mu \mathrm{M}$ IBA.

Low $\mathrm{pH}$ media $(\mathrm{pH} 4.0)$ generally achieved negative effect on rooting percentage except for higher concentration of TIBA (ACM3) where it was at the level of rooting percentage at analog medium with $\mathrm{pH} 5.5$ (ACM6). Lower rooting percentage on low $\mathrm{pH}$ is in accordance with results of Vuksanović et al. (2017) that they obtained also on media without growth regulators and the same $\mathrm{pH}$ in white poplar clones in vitro. Inhibitory effect of low $\mathrm{pH}$ was also reported by Long et al. (2017) in hydroponics. They found that high concentrations of $\mathrm{H}^{+}$ions can produce toxicity symptoms and direct damage of roots of citrus by influencing import of essential minerals and water. However, according to Kovačević et al. (2013b), in medium that was not buffered with citric acid but initially adjusted to pH3.0 with 1M $\mathrm{HCl}$, the stimulative effect on rooting of white poplar microshoots could be obtained. 
Pruski (2007) reports that enhanced root induction after treatment with $2 \mathrm{mg} / \mathrm{l} \mathrm{IBA}$ in vivo was found in Prunus tomentosa, Prunus fructicosa, Prunus verginiaca and Prunus pensylvanica. According to Zhou et al. (2010) use of IBA in concentrations of 4.92 and $7.38 \mu \mathrm{M}$ resulted in $100 \%$ rooting in Prunus persica $\times$ P. davidiana in vitro.

Inhibitory effect of TIBA, as an inhibitor of polar transport of auxins, is in concordance with general opinion (McNamara and Mitchell, 1991). Kovačević et al. (2013a) recorded inhibitory effect of low concentrations of TIBA $(0.1 \mu \mathrm{M})$ on rooting in two black locust genotypes in vitro. However, values of length of the longest roots were the highest on two media with TIBA: ACM3 and ACM6. Also, Kovačević et al. (2013a) did found positive effect of $1 \mu \mathrm{M}$ TIBA on number of roots in hard-to-root genotype Rózsaszín AC. They suggested that manipulations with auxins' accumulation site and sensitivity to auxins could increase intensity of the formation of root system, and proposed use of TIBA for improvement of microshoot rooting in some specific cases.

Table 6. Coefficients of correlation and significance of z-test for examined traits in P. avium cl. 8A. a)

\begin{tabular}{lcccc}
\hline & $\begin{array}{c}\text { Number of } \\
\text { first-order roots }\end{array}$ & $\begin{array}{c}\text { Shoot height } \\
(\mathrm{mm})\end{array}$ & $\begin{array}{c}\text { Length of the } \\
\text { longest root }(\mathrm{mm})\end{array}$ & $\begin{array}{c}\text { Survival } \\
\text { rate (\%) }\end{array}$ \\
\hline Shoot height & 0.408 & & & \\
Length of the longest root & $\mathbf{- 0 . 7 2 4}$ & 0.145 & & \\
Survival rate & -0.517 & 0.362 & $\mathbf{0 . 6 5 9}$ & \\
Rooting percentage & $\mathbf{0 . 8 2 8}$ & 0.319 & -0.390 & -0.423 \\
\hline
\end{tabular}

a) Bolded coefficients of correlation are significantly different from 0 at the level of $\alpha=0.05$

According to coefficients of correlation between measured traits, there is high negative correlation between number of roots and length of the longest root, and high positive correlation between length of the longest root and survival rate, as well as between number of roots and rooting percentage which is in accordance with the results of Vuksanović (2019c), obtained in rooting of five white poplar genotypes.

\section{Conclusion}

Results of the study suggest that both concentration and type of auxin influenced rooting percentage of wild cherry shoots in vitro. The best rooting and shoot growth were obtained on medium based on modified MS with pH 5.8 and $20 \mu \mathrm{M}$ IBA (K2). Only favorable result obtained in media with TIBA was better root growth. Further research should be directed to a larger number of genotypes by implementation of same or similar methodology.

\section{Acknowledgments}

This study was financed by the Ministry of Education, Science and Technological Development of the Republic of Serbia (Project No: 451-03-68/2020-14/ 200117 and 451-03-68/2020-14/200197).

\section{References}

1. Ahuja, M.R. (1984): A commercially feasible micropropagation method for aspen. Silvae genetica 33(4/5): 174-176.

2. Buyukdemirci, H. (2005): The effects of medium ingredients on shoot propagation and rooting of cherry rootstocks in vitro. In V International Cherry Symposium 795, June 2005: 419-422.

3. Canli, F.A., Demir, F. (2014): In vitro multiplication and rooting of 'F12-1'(Prunus avium L.) and 'Maxma 14'(Prunus mahaleb L.× P. avium L.) rootstocks. Indian Journal of Horticulture 71(2): 145-150. 
4. Diaz, R., Merlo, E. (2008): Genetic variation in reproductive traits in a clonal seed orchard of Prunus avium in northern Spain. Silvae Genetica 57(1-6): 110-118.

5. Ďurkovič, J. (2006): Rapid micropropagation of mature wild cherry. Biologia Plantarum 50(4): 733-736.

6. Fotopoulos, S., Sotiropoulos, T.E. (2004): In vitro propagation of the peach rootstock: the effect of different carbon sources and types of sealing material on rooting. Biologia plantarum 48(4): 629-631.

7. Katičić Bogdan, I., Švorinić, K., Bogdan, S., Kajba, D. (2015): Generative and vegetative activity of wild cherry (Prunus avium L.) in a clonal seed orchard. Šumarski list 139(7-8): 339-348.

8. Kobliha, J. (2002): Wild cherry (Prunus avium ild cherry (L.) breeding program aimed at the use of this tree in the Czech forestry. Journal of Forest Science 48(5): 202-218.

9. Kovačević, B., Orlović, S., Katanić, M. and Vasić, S. (2013a): Influence of 2, 3, 5-triiodobenzoic acid and silver ions on rooting in Robinia sp. in vitro. Topola (191-192): 91-100.

10. Kovačević B., Miladinović D., Katanić M., Tomović Z., Pekeč S. (2013b): The effect of low initial $\mathrm{pH}$ on in vitro white poplar growth. Bulletin of the Faculty of Forestry, 108: 67-80.

11. Kumar, A., Sharma, V., Thakur, M. (2020): In vitro rooting and hardening of clonal cherry rootstock Gisela 5 (Prunus cerasus $\times$ Prunus canescens). International Journal Agricultural Sciences 90 (5): 1032-1035.

12. Long, A., Zhang, J., Yang, L.T., Ye, X., Lai, N.W., Tan, L.L., Lin, D., Chen, L.S. (2017): Effects of low $\mathrm{pH}$ on photosynthesis, related physiological parameters, and nutrient profiles of citrus. Frontiers in plant science 8: 1-22.

13. Mansseri-Lamrioui, A., Louerguioui, A., Bonaly, J., Yakoub-Bougdal, S., Allili, N., GanaKebbouche, S. (2011): Proliferation and rooting of wild cherry: The influence of cytokinin and auxin types and their concentration. African Journal of Biotechnology 10(43): 8613-8624.

14. McNamara, S.T., Mitchell, C.A. (1991): Roles of Auxin and Ethylene in Adventitious Root Formation by a Flood-resistant Tomato Genotype. HortScience 26(1): 57-58.

15. Murashige, T., Skoog, F. (1962): A revised medium for rapid growth and bioassays with tobacco tissue cultures. Physiology of Plants 15: 473-497.

16. Poljaković-Pajnik, L., Drekić, M., Kovačević, B., Stanković-Neđić, M., Stojnić, S., Orlović, S. (2019): Host preference of Myzus cerasi (Fabricius, 1775) to half-sib lines of Prunus avium L. from six populations assessed in the nursery trial. Topola 203: 87-94.

17. Pruski, K. (2007): Tissue culture propagation of Mongolian cherry (Prunus fruticosa L.) and Nanking cherry (Prunus tomentosa L.). In Protocols for Micropropagation of Woody Trees and Fruits (pp. 391-407), Springer, Dordrecht.

18. Ružić, D.V., Vujović, T.I. (2008): The effects of cytokinin types and their concentration on in vitro multiplication of sweet cherry cv. Lapins (Prunus avium L.). Horticultural Science 35(1): 1221.

19. Sarropoulou, V., Dimassi-Theriou, K., Therios, I. (2014): L-arginine impact on cherry rootstock rooting and biochemical characteristics in tissue culture. Turkish Journal of Agriculture and Forestry 38(6): 887-897.

20. Šiško, M. (2011): In vitro propagation of Gisela 5 (Prunus cerasus $\times$ P. canescens). Agricultura (Slovenia) 8(1): 31-34.

21. Stanković-Neđić, M., Stojnić, S., Orlović, S., Čolić, H., Petrović, D., Isajev, V. (2018): Variability of seed germination and morphological properties of seedlings of Wild cherry populations from Republic of Srpska (BiH). Topola 201-202: 213-225.

22. Tančeva Crmarić, O., Kajba, D. (2016): Micropropagation of wild cherry (Prunus avium L.) from a clonal seed orchard. Šumarski list 140(5-6): 273-281.

23. TIBCO, (2017): Software Inc. Statistica (data analysis software system), version 13.

24. Vuksanović, V., Kovačević, B., Orlović, S., Miladinović, D., Kebert, M., Katanić, M. (2017): Changes in medium pH during white poplar micropropagation. Topola (199-200): 153-165. 
25. Vuksanović, V., Kovačević, B., Orlović, S., Kebert, M., Kovač, M. (2019a): The influence of drought on growth and development of white poplar shoots in vitro. Topola 203: 13-18.

26. Vuksanović, V., Kovačević, B., Kebert, M., Katanić, M., Pavlovic, L., Kesić, L., Orlovic, S. (2019b). Clone specificity of white poplar (Populus alba L.) acidity tolerance in vitro. Fresenius Environmental Bulletin 28(11): 8307-8313.

27. Vuksanović, V. (2019c): Tolerantnost selekcija bele topole prema abiotičkim činiocima u uslovima in vitro. Doktorska disertacija, Univerzitet u Novom Sadu - Poljoprivredni fakultet (143).

28. Xu, J., Kang, I.K., Kim, C.K., Han, J.S., Choi, C. (2015): Optimization of apical tip culture condition for In Vitro propagation of 'Gisela 5'dwarf cherry rootstock. Journal of Plant Biotechnology 42(1): 49-54.

29. Zamanipour, M., Moghadam, E.G., Tehranifar, A. Abedi, B. (2015): The effects of media, plant growth regulators and apex size on the success of meristem culture in Prunus avium cv pishrase-mashhad. Indian Journal of Fundamental and Applied Life Sciences, 2015(5): 924-929.

30. Zhou, H., Li, M., Zhao, X., Fan, X., Guo, A. (2010): Plant regeneration from in vitro leaves of the peach rootstock 'Nemaguard' (Prunus persica× P. davidiana). Plant Cell, Tissue and Organ Culture (PCTOC) 101(1): 79-87. 